WIACZESŁAW PATRIN, WOŁGOGRAD, ROSJA

ORCID: 0000-0001-6376-5076

\title{
NAUKA ŚW. MARKA EREMITY O CNOCIE
}

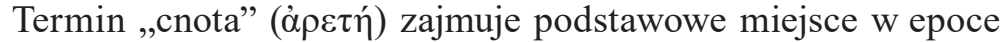
starożytności. Wszedł on również do słownictwa chrześcijańskich autorów. Dla współczesnego człowieka termin ten stracił trochę swój pierwotny sens, co w sumie związane jest z pewną dechrystianizacją kultury europejskiej. Nie wchodząc we wszystkie szczegóły tego procesu, można zaznaczyć, że w pewnym stopniu jest on związany z utratą sensu chrześcijańskiej moralności. Kiedy zwracamy się do tekstów starożytnych chrześcijańskich autorów, naszym celem jest zgłębianie znaczeń poszczególnych pojęć, które umożliwiały chrześcijanom realne doświadczenie chrześcijańskiego szczęścia w relacji z Bogiem i w przemienianiu swojej natury. Tak więc, celem naszej

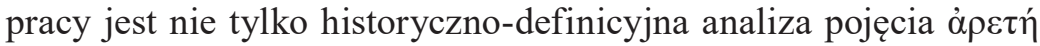
u św. Marka Eremity, ${ }^{1}$ ale i aktualizacja jego nauczania dla współczesnego człowieka przez pryzmat danych współczesnej psychologii.

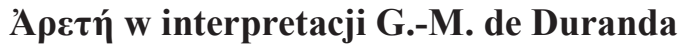

Według indeksu greckich słów dla dzieł św. Marka Eremity, ${ }^{2}$

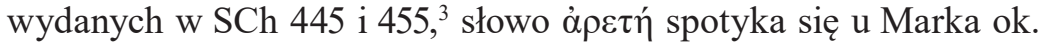

1 Wykorzystaliśmy rosyjskie tłumaczenie św. Marka Eremity: Слова духовно-нравственные преподобных отцов наших Марка Подвижника, Исайи Отшельника, Симеона Нового Богослова, Москва 1995 (cytaty z Marka Eremity w przekładzie polskim są tłumaczone z rosyjskiego).

2 Marek Eremita jest czczony jako święty w Kościołach o tradycji wschodniej.

3 Marc le Moine, Traités. Wstęp i tłum G.-M. de Durand, t. 1, Paris 1999 (dalej: SCh 445); t. 2, Paris 2000 (dalej: SCh 455). 
50 razy (my naliczyliśmy 51 razy). ${ }^{4}$ Najczęściej to pojęcie spotyka się w dziele De his qui putant se ex operibus justificari (dalej: Justif.) - występują 23 przypadki jego użycia. Francuski wydawca

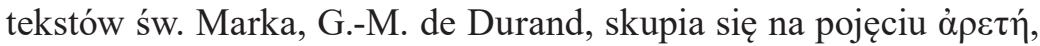
komentując rozdziały 194-195 traktatu De lege spirituali (dalej: Leg.): „Jedną rzeczą jest wypełnienie przykazania, a drugą cnota; chociaż jedno z drugiego czerpie pobudzenie ku dobremu”. "Wypełnieniem przykazania nazywa się to, kiedy wypełniliśmy to, co nam kazano, natomiast cnotą - kiedy to, co zostało uczynione, naprawdę podoba się [Bogu]". 6

Naukowiec zaznacza, że te rozdziały powtarzają nauczanie Arystotelesa o tym, że „za oznakę trwałych dyspozycji uważać należy przyjemność lub przykrość, które towarzyszą czynnościom". ${ }^{7}$ Według

4 Zob. SCh 455, s. 362.

5 Марк Под в и жн и к, О законе духовном, 193/194, SCh 445, s. 124. W rosyjskim tłumaczeniu św. Marka Eremity numeracja rozdziałów trochę się różni od przedstawionej w krytycznym wydaniu G.-M. de Duranda. W tym artykule na pierwszym miejscu będzie znajdować się numeracja przyjęta w rosyjskim przekładzie, a potem numeracja z krytycznego wydania.

6 Tamże, 194/195, s. 126. W używanym rosyjskim przekładzie grecki czasownik

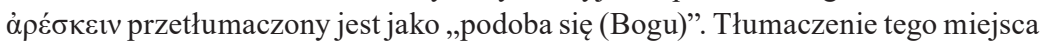
przez św. Teofana Rekluza nieco się różni, ale zachowuje ten sam sens co i czasow-

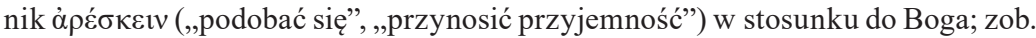
t e n ż e, 200 глав о духовном законе. Добротолюбие в русском переводе [еп. Феофана Затворника], дополненное. В 5-ти томах, Св.-Тр. Сергиева Лавра 1992, t. 1, s. 537. W związku z występowaniem różnic w tłumaczeniu tego rozdziału, tutaj

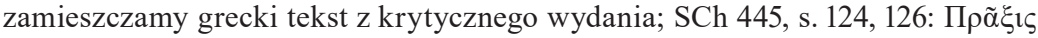

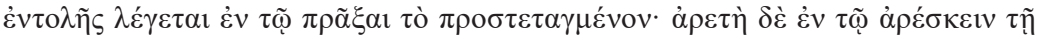

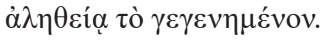

7 Ten fragment u Arystotelesa brzmi następująco: „Za oznakę trwałych dyspozycji uważać należy przyjemność lub przykrość, które towarzyszą czynnościom; bo kto wyrzeka się rozkoszy zmysłowych i to właśnie go raduje, ten jest umiarkowany; kto zaś odczuwa to jako ciężar, jest rozwiązły; kto naraża się na niebezpieczeństwa i to go cieszy lub przynajmniej nie sprawia mu przykrości, ten jest mężny, kto zaś przy tym odczuwa przykrość, jest tchórzem. Przyjemności bowiem i przykrości tyczy się dzielność etyczna. Wszak ze względu na przyjemność dopuszczamy się czynów niecnych, a ze względu na przykrość wstrzymujemy się od czynów 


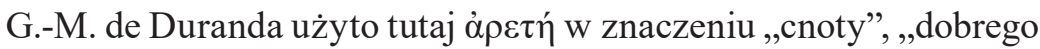
moralnego usposobienia". Dalej autor porównuje używanie tego słowa z bliskim semantycznie fragmentem z traktatu De baptismo (dalej: Bapt.) V 9-11, gdzie św. Marek pisze: „Jeśli bez przykrości, ale z radością i pracowitością praktykujemy wyżej opisane cnoty, oznacza to, że umysł nasz nie jest pożądliwy". ${ }^{8}$ Badacz zwraca uwagę na

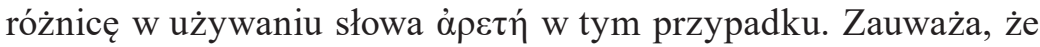

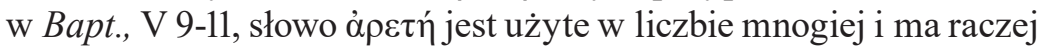
sens „dobrych wyników” (performances), „osiągnięć” (prouesses). Podobne znaczenie, według badacza, słowo to zachowuje i w Bapt., V 245-265. ${ }^{9}$ Przy tym ostatnim fragmencie autor zwraca uwagę na ważny szczegół: św. Marek oddziela chęć człowieka do dobrego czynu od jego wypełnienia, ostatnie jest możliwe tylko dzięki mocy Chrystusa (l'action du Christ).

G.-M. de Durand wykazuje pewne niezrozumienie w używaniu

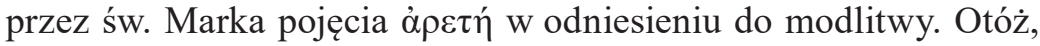
kiedy w dziele Disputatio cum quodam causidico (dalej: Causid.) jest mowa o pokorze jako ,wielkiej cnocie”, to, według badacza, jest ono zrozumiałe w kontekście chrześcijańskiej tradycji. Ale w tym, że św. Marek nazywa nierozproszoną modlitwę „świętą cnotą" (Causid., IV 33), ${ }^{10}$ Durand widzi niespójność, bo, jego zdaniem, w tym przypadku jest mowa raczej o, podstawowej praktyce” w życiu ascety, lub w ogóle chrześcijanina, niż o cnocie jako takiej. Dalej Durand

pięknych"; A r y s t o te le s, Etyka nikomachejska, II 3, tłum. D. G ro m s k a, Wydawnictwo Naukowe PWN, Warszawa 2007.

8 М ар к Под в и жн и к, Ответ недоумевающим о святом Крещении, tłum. ros., s. 87 , SCh 445, s. 326.

9 Zob. tamże, tłum. ros., s. 95, SCh 445, s. 346: „Dlatego nie powinno się uważać, że niby grzech Adama wykorzenia się ascezą, podobnie jak i własne grzechy po chrzcie, lecz tylko Jezusem Chrystusem: «Albowiem to Bóg jest w was sprawcą i chcenia, i działania zgodnie z [Jego] wolą» (Flp 2, 13). Dodając «zgodnie z Jego wolą», Apostoł pokazuje, że mieć wolę do czynienia cnót zależy od nas, ale czynić cnoty lub wykorzenić grzechy, bez Boga jest niemożliwe".

10 Zob. te n ż e, Прение схоластика с аввою Марком, tłum. ros., s. 127, SCh 455, s. 36 . 


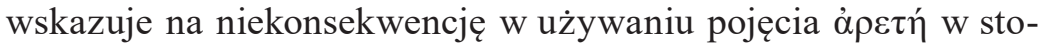
sunku do modlitwy w traktacie De his qui putant se ex operibus justificari. Otóż, jeśli w Justif. 33 św. Marek pisze, że modlitwa jest raczej „matką cnót” niż samą cnotą, ${ }^{11}$ to w tymże traktacie, Justif. 93, umieszcza modlitwę i cnotę w jednym rzędzie. ${ }^{12}$

Na końcu swojej pojęciowej analizy Durand dochodzi do wnio-

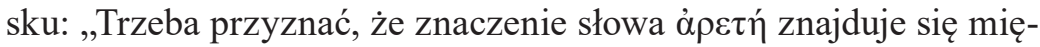
dzy dwoma biegunami: «działanie» i «stan» (č $\xi 1 \varsigma$ - habitus). Stan wewnętrzny, będąc niewidzialny, zazwyczaj ujawnia się poprzez działanie (...). W autentycznych tekstach św. Marka należy tłuma-

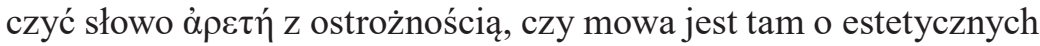
cechach, czy o ascetycznych czynach (Bapt., V 9-15), św. Marek wielokrotnie wskazuje na to, że to wszystko nie odnosi się tylko do działania człowieka, lecz dokonuje się dzięki współpracy z Duchem Świętym. W innym przypadku, cnota nie wykracza poza ramy zwykłego unikania grzechu (Justif., 24) i raczej jest rozwojem natury w prawidłowym kierunku, i rozumie się ją jako spełnienie przykazań (Bapt., III 40)".

W ten sposób wydawca tekstów św. Marka wskazuje na trudność

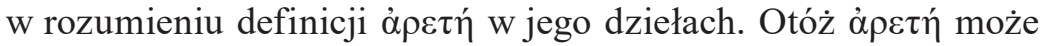
oznaczać albo predyspozycję ku dobremu (coś, co jest w potencjalności), albo coś, co już zostało osiągnięte, aktualizowane. Szczególne

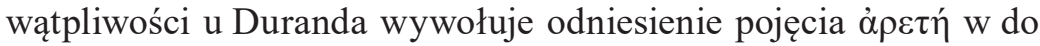
modlitwy. Modlitwa jest i jedną z cnót, i matką wszystkich cnót; modlitwa również może się znajdować $\mathrm{w}$ jednym rzędzie z cnotami, jako coś, co jest do nich podobne, ale jednak inne. W ramach naszego badania spróbujemy odpowiedzieć na te pytania Duranda.

1 Zob. te n że, O тех, которые думают оправдаться делами, 35, tłum. ros., s. 33, SCh 445, s. 140.

12 Tamże, 101, tłum. ros., s. 40, SCh 445, s. 158: „Dobrze słowami nauczać pytających, ale lepiej towarzyszyć im modlitwą i cnotą: albowiem za pośrednictwem tych ostatnich przynoszący siebie Bogu pomaga i bliźnim poprzez pomoc, którą sam otrzymuje". 


\title{
Uzupełnienie analizy G.-M. de Duranda
}

\author{
Klasyczne schematy
}

Przede wszystkim zatrzymajmy się na klasycznych schematach, które spotykamy w nauce św. Marka o cnotach. Wykorzystuje on klasyczny schemat czterech cnót koniecznych do zbawienia: „Kto chce przekroczyć duchowe morze, ten niech zachowuje dzielność ducha

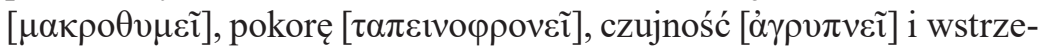

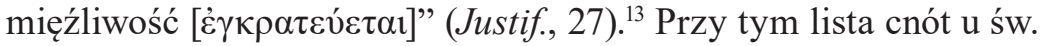
Marka absolutnie różni się od tej, która przyjęła się w klasycznej filozofii greckiej i którą spotyka się u wielu Ojców Kościoła (św. Bazyli Wielki, Grzegorz Wielki, Grzegorz z Nazjanzu, Grzegorz z Nyssy).

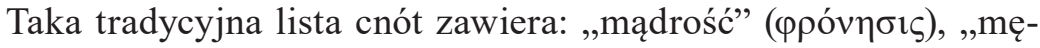

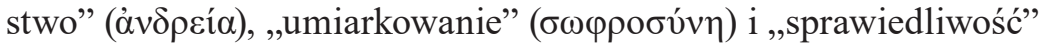

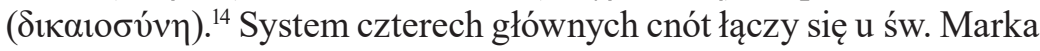
z innym etycznym pojęciem - $\alpha \pi \alpha ́ \theta \varepsilon ı \alpha$ (,beznamiętność”), a także

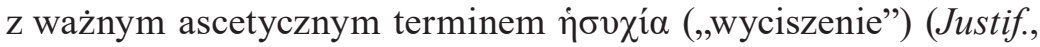
28). ${ }^{15} \mathrm{~W}$ innym przypadku (Paen., VII 2), mówiąc o nawróceniu, św. Marek zaznacza trzy cnoty: oczyszczenie myśli, nieustanną modlitwę i cierpliwe znoszenie spotykających nas przykrości. ${ }^{16}$ Trójskładowe schematy w zasadzie są znane dla chrześcijańskiej tradycji. Oprócz słów Pawła Apostoła o wierze, nadziei i miłości, ${ }^{17}$ można przytoczyć

13 Tamże, 39, tłum. ros., s. 32-33, SCh 445, s. 138.

14 Zob. Л. Р. Ф о к и н, П л а т о н (Игумнов), архим., Понятие добродетели в патристической традиции, Православная энциклопедия, t. 15, Москва 2007, s. $478-479$.

15 М ар к Под в и ж н и к, О тех, которые думают оправдаться делами, 30, tłum. ros., s. 33, SCh 445, s. 138: „Milczenie jest odcinaniem się od zła. Jeśli bowiem do modlitwy dołączyć i te cztery cnoty, to nie ma lepszego sposobu do osiągnięcia beznamiętności”.

16 Zob. te n że, O покаянии всегда и всем необходимом, tłum. ros., s. 67, SCh 445, s. 234: „Z tego powodu uważam, że dzieło nawrócenia odbywa się trzema następującymi cnotami: oczyszczeniem myśli, nieustanną modlitwą i cierpliwym znoszeniem spotykających nas przykrości”.

17 Zob. 1Kor 13, 13: „Tak więc trwają wiara, nadzieja, miłość - te trzy: największa z nich jednak jest miłość". 
słowa św. Antoniego Wielkiego, który w swoich rozważaniach często wykorzystywał trójskładowe schematy. ${ }^{18}$ Do chrześcijańskiej tradycji nawiązują także rozważania św. Marka o miłości jako ostatniej na liście, ale przy tym najważniejszej cnoty (Justif., 35). ${ }^{19} \mathrm{~W}$ ten sposób

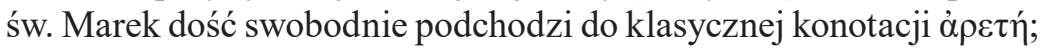
nie używa starożytnego czteroskładowego schematu, lecz wskazuje na całkiem świeży schemat, który odzwierciadla podstawy mniszej tradycji.

\section{Cnota i modlitwa}

Analizę naświetlonych przez G.-M. de Duranda logicznych sprzeczności, związanych z używaniem przez św. Marka poję-

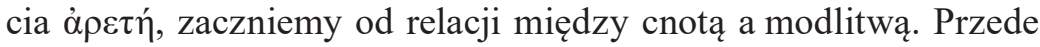
wszystkim, według naszej opinii, Durand nie do końca poprawnie zidentyfikował sens, w jakim „nierozproszona modlitwa” nazywa się

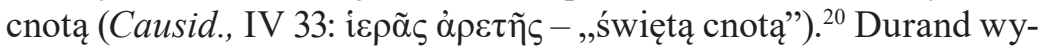
ciągnął wniosek, że mowa jest o ,głównej praktyce” w życiu ascety albo chrześcijanina, tzn. o modlitwie jako o działaniu. Według nas, bardziej prawidłowe będzie tutaj rozumienie cnoty w sensie właściwego usposobienia duszy podczas modlitwy. Nie każda modlitwa jest nierozproszona, a właśnie nierozproszenie w modlitwie jest oznaką cnoty. W tym przypadku św. Marek reprezentuje tradycję egipskiego

18 Zob. Достопамятные сказания о подвижничестве святых и блаженных отизов (Apoftegmaty). Пер. с греч., сост. при Московской Духовной Академии, Москва 1855, Антоний 3. 11. 22 (posługujemy się wydaniem: Киев 2001, s. 5-6. 10).

19 М ар к Под в и жн и к, О тех, которые думают оправдаться делами, 37, tłum. ros., s. 33, SCh 445, s. 140: „Kiedy usłyszysz, że «wielu pierwszych będzie ostatnimi, a ostatnich pierwszymi» (Mt 19, 30), to zrozum, że to jest o mających cnoty i miłość. Albowiem miłość jest ostatnia z cnót według rzędu, ale pierwsza ze wszystkich według godności, i to, co poprzedzało ją, czyni ostatnim”.

20 Zob. t e n ż e, Прение схоластика с аввою Марком, tłum. ros., s. 127, SCh 445, s. 36: „Albowiem pierwsze jest oznaką pychy, a ostatnie - pokory (...), przez którą On i doprowadza nas nie tylko do poznania, ale i do nawyku świętej cnoty, to znaczy nierozproszonej modlitwy". 
monastycyzmu, którą możemy dostrzec w dziełach Ewagriusza ${ }^{21}$ i w Apoftegmatach. ${ }^{22} \mathrm{~W}$ takim razie, biorąc pod uwagę słowa św. Marka o hezychii i o roli modlitwy w jej osiągnięciu, można stwierdzić, że przynależał on do tradycji hezychazmu, w której rozwinęła się praktyka nieustającej modlitwy - „modlitwy Jezusowej”.

Jeśli chodzi o związek przyczynowo-skutkowy między modlitwą a cnotą, to powiedzenie, że modlitwa jest „matką cnót”, było powszechnie używane w tradycji bizantyjskiego monastycyzmu. W ten sam sposób co św. Marek pisze o modlitwie św. Jan Klimak w Drabinie do raju, którą tak oto określa: „O matce cnót, świętej i błogosławionej modlitwie, i o trwaniu w niej umysłem i ciałem" (rozdz. 28). Przy czym św. Jan stosuje przeciwstawienie, nazywając modlitwę i matką, i córką cnoty łez (tamże, 28, 1). ${ }^{23} \mathrm{~W}$ tym kontekście słowa św. Marka nie wydają się nazbyt dziwne, jak to przedstawia G.-M. de Durand. Nie możemy z pewnością stwierdzić, czy św. Marek był pierwszym, który nazwał modlitwę „matką cnót”, ale bez wątpienia stwierdził to długo przed św. Janem Klimakiem.

Niekonsekwencję w ujmowaniu związku przyczynowo-skutkowego pomiędzy modlitwą a cnotą można wyjaśnić, na przykład, przez zwrócenie się do współczesnej psychologii, do pojmowaniu świadomości jako procesu (por. strumień świadomości u Williama Jamesa $^{24}$ ). W tym strumieniu różne psychiczne struktury, elementy i procesy są powiązane ze sobą (jedne myśli albo uczucia rodzą

21 Zob. Ев агрий Понтийский, Слово о молитве, 35 , w: А. И. Си д о р о в (пер., вступ. ст. и комм.), Творения аввы Евагрия: Аскетические и богословские трактаты, Москва 1994, s. 81: „Nierozproszona modlitwa jest najwyższym myśleniem umysłu".

22 Zob. Древний патерик, изложенный по главам. Пер. с греч. Афонского Русского Пантелеймонова монастыря, Москва 1899 (репринт: Москва 1991), Апофтегма XII, 2 (Агафон 9): „Bracia zapytali abba Agafona, mówiąc: Jaka cnota w ascezie wymaga największego wysiłku? On odpowiada: Wybaczcie mi, nie ma większego trudu, jak modlić się do Boga bez rozproszenia...".

23 Zob. И. Л е с т в и ч н и К, Лествица, возводящая на небо, Москва 2001, s. 437.

24 Zob. У. Д же м с, Психология, Москва 1991, s. 56-70. 
inne, często zmieniające się). Modlitwa wpływa na stan człowieka i odwrotnie, stan człowieka, w tym przypadku związany ze łzami, wpływa na modlitwę, na jej jakość. W ten sposób, modlitwa jest działaniem, które wpływa na ludzkie usposobienie, a siła oddziaływania zależy od tego, na ile uważnie i w skupieniu człowiek się modli. W tym sensie nierozproszona modlitwa stanowi modlitwę dobrej jakości. W tym kontekście można przypomnieć o występo-

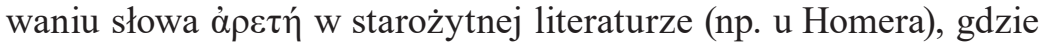
oznacza ono rzetelność, dobrą jakość. ${ }^{25} \mathrm{~W}$ ten sposób, odnoszenie pojęcia $\dot{\rho} \rho \tau \imath \dot{~ d o ~ n i e r o z p r o s z o n e j ~ m o d l i t w y ~ c a ł k i e m ~ d o b r z e ~ w p i s u j e ~}$ się w tradycję klasycznego używania tego słowa.

Co się tyczy określania modlitwy jako „matki cnót”, to łączy się ono z chrześcijańską tezą, że źródłem wszelkiego dobra jest Bóg. Przez modlitwę człowiek otrzymuje łaskę Bożą, która pomaga mu zdobyć kolejne cnoty. W tym kluczu, modlitwa nazywa się „matką cnót”, a także ,świętą cnotą", albowiem jest ona pośredniczką między Bogiem a człowiekiem i przez nią człowiek otrzymuje także pomoc od Boga w osiąganiu cnót. Jak o tym mówi św. Marek: „I modlitwa nazywa się cnotą, chociaż ona jest matką cnót, albowiem rodzi ją przez komunię z Chrystusem" (Justif., 33). ${ }^{26}$

\section{Cnota jako dzieło natury}

Z całości rozważań św. Marka uwagę przyciągają słowa o cnocie jako „,ziele natury”: „Każda cnota, praktykowana do śmierci, jest niczym innym, jak oddaleniem się od grzechu, oddalenie się od grzechu jest zaś dziełem natury ( $\varphi v ́ \sigma \varepsilon \omega \varsigma$ ع̌ $\rho \gamma o v$ ), a nie ceną królestwa" (Justif., 24). ${ }^{27}$ We współczesnej Encyklopedii Prawosławnej nauczanie św. Marka o cnocie w sumie wypływa z powyższego tekstu: „Św. Ma-

25 Zob. A. А. Г у с ей н о в, История этических учений, Москва 2015, s. 293-297.

26 М ар к Под в и ж н и к, O тех, которые думают оправдаться делами, 35, tłum. ros., s. 33, SCh 445, s. 140.

27 Tamże, 24, tłum. ros., s. 32, SCh 445, s. 138. 
rek rozumiał cnotę jako «powstrzymanie się od grzechu» ( $\alpha \mu \alpha \rho \tau i ́ \alpha \varsigma$ $\dot{\alpha} \pi \circ \chi \eta ́)$, które jest «dziełem natury», tzn. opiera się na naturalnych zdolnościach człowieka, a nie na łasce Bożej”. ${ }^{28}$ Wyprowadzenie takiego wniosku, że św. Marek uważa, iż cnota „opiera się na naturalnych zdolnościach człowieka, a nie na łasce Bożej”, przeczy jego nauczaniu, gdy pisał, że źródłem cnót jest Bóg, a człowiek może jedynie ich pragnąć (Leg., 40; Bapt., V 250). ${ }^{29}$

Słowa św. Marka o cnocie jako naturalnym działaniu ( $\varphi v ́ \sigma \varepsilon \omega \varsigma$

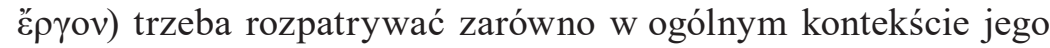
rozważań o cnocie, jak i w kontekście całej wschodniej myśli patrystycznej. U autorów wschodniochrześcijańskich charakterystyczne było bardziej optymistyczne spojrzenie na ludzką naturę niż u św. Augustyna. Po pierwsze, ludzka natura była rozumiana jako ukierunkowana na dobro, po drugie, łaska Boża była rozpatrywana jako „część” ludzkiej natury, bez której człowiek jest niepełny. ${ }^{30} \mathrm{~W}$ ten sposób, być cnotliwym w synergii z Bożą łaską, oznaczało żyć zgodnie ze swoją naturą. Takim sposobem, pragnienie cnoty oznacza pragnienie czegoś naturalnego, a pragnienie czegoś grzesznego oznacza pragnienie czegoś przeciwnego własnej naturze.

Tak oto słowa św. Marka skierowane są przeciwko rozumieniu cnót jako zasług przed Bogiem. Cnoty nie są zasługami, lecz słusznym stanem zgodnym z naturą; dlatego człowiek otrzymuje zbawienie od Boga nie według swoich zasług, nawet jeśli wykazuje się cnotami. Przy czym samych cnót nie można osiągnąć bez łaski Bożej. Jak już

28 Л. Р. Ф о к и н, П л а то н (Игумнов), архим., Понятие добродетели в патристической традииии, s. 483.

29 Św. Marek uważa, że Bóg jest źródłem cnót; zob. М а р к По д в и жн и к, О законе духовном, 40, tłum. ros., s. 87, SCh 445, s. 186: „Początkiem każdej cnoty jest Bóg, jak i dziennego światła - słońce"; t e n ż e, Ответ недоумевающим о святом Крещении, V 250, tłum. ros., s. 95, SCh 445, s. 346: „Pragnąć cnót zależy od naszej woli, a czynić je lub wykorzeniać grzechy, bez Boga jest niemożliwe".

30 Zob. np. św. Grzegorz z Nyssy, według którego w ludzką naturę jest wpisana

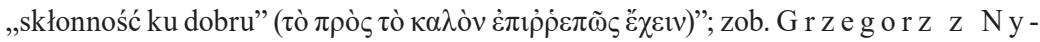
s s y, De beatitudinibus, 5, PG 44, 1249. 1256; cyt. za: Л. Р. Ф о к и н, П л а т о н (Игумнов), архим., Понятие добродетели в патристической традиции, s. 479. 
zostało powiedziane, człowiek może tylko chcieć być cnotliwy, ale tak naprawdę osiąga dobre, poprawne, wewnętrzne usposobienie tylko za pomocą łaski Bożej, przez modlitwę. Okazuje się, że i cnoty nie są jego zasługą, człowiek może tylko przez swoją wolę dać albo nie dać łasce możliwość realizowania się w nim cnoty. ${ }^{31}$

W ten sposób, rozważania św. Marka o cnocie jako o „dziele natury", noszą antropologiczno-aksjologiczny charakter. Charakter ten wskazuje na miejsce cnót w chrześcijańskim systemie wartości. Wartość zbawienia jest wyższa od posiadania cnót. Zbawienie nie jest „dziełem natury”, ale wyłącznie dziełem łaski Bożej. Łaska uzdrawia ludzkie namiętności, pomagając człowiekowi stać się cnotliwym. Tymczasem zbawienie - to nie tylko uzdrowienie ludzkiej natury, przywrócenie jej właściwego stanu, lecz dzieło, które wychodzi poza granice ludzkich naturalnych możliwości.

$* * *$

W dziełach św. Marka Eremity pojęcie cnoty występuje na trzech poziomach: teologiczno-spekulatywnym; antropologiczno-aksjologicznym i ascetyczno-praktycznym.

Na poziomie teologiczno-spekulatywnym św. Marek dzieli się swoimi rozważaniami o cnocie w traktacie De lege spirituali. W tym przypadku jest mowa o Bogu jako źródle cnót i o tym, że natura cnoty pozostaje jedna, ale różni się w jej praktycznej realizacji. ${ }^{32}$

31 Zob. М ар к Под в и ж н и к, Ответ недоумевающим о святом Крещении, IX 78-79, tłum. ros., s. 101, SCh 445, s. 362: „Ile dziś dołożyłeś do cnoty, tyle okazałeś się dłużnym w poprzedniej, jednak pokazałeś siłę swojej natury: albowiem dzisiejsze dołożeniem ujawniło, że wczorajsza niedostateczność zależała nie od natury, lecz od woli”.

32 Idea jedności cnót, które dzielą się na cztery pochodne cnoty: „mądrość”

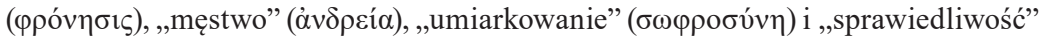

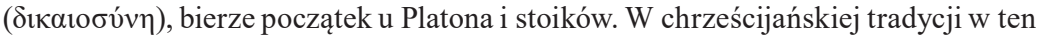
sposób wypowiadali się między innymi św. Klemens Aleksandryjski i św. Grzegorz z Nazjanzu; zob. Л. Р. Ф о к и н , П л а т о н (Игумнов), архим., Понятие добродетели в патристической традиции, s. 478-479. 
Antropologiczno-aksjologiczny poziom cnoty św. Marek rozpatruje w Justif., 24 i Bapt., IX 78-79. W tym przypadku można zauważyć dążenie autora do podkreślenia roli Boga i Jego łaski w dziele zbawienia człowieka. Zbawienie rozpatruje się jako działanie, które przewyższa ludzką naturę, a cnota pozostaje naturalnym stanem człowieka, który z kolei nie jest możliwy bez pomocy łaski Bożej.

Ascetyczno-praktyczny poziom pozostaje związany ze spojrzeniem na cnotę w kontekście modlitwy. Modlitwa jest pośredniczką między Bogiem a człowiekiem. Przez nią człowiek otrzymuje łaskę, która rodzi w nim cnoty, dlatego stanowi ona „matkę cnót”. Z drugiej strony, jakość modlitwy zależy od stanu człowieka. Prawdziwą, nierozproszoną modlitwę wzbudza w człowieku stan płaczu. Taka niekonsekwencja pokazuje, że w tym przypadku św. Marek rozważa i opisuje procesy, które pojawiają się w duszy ascety, nie w doktrynalno-logicznym, lecz w fenomenologicznym kluczu.

ks. Wiaczesław PATRIN

(z rosyjskiego ttum. Karina Gribanova)

Słowa kluczowe: Marek Eremita; modlitwa; cnota

Keywords: Mark the Ascetic; prayer; virtue

\section{Marc the Ascetic's learning about virtue Summary}

In the works of St. Mark the Ascetic, the notion of virtue exists on three levels: 1) theological-speculative, 2) anthropological-axiological and 3) ascetic-practical. On the theological-speculative level, Mark shares his reflections on virtue in the treatise De lege spirituali. In this case, he speaks about God as the source of virtues and about the fact that the nature of virtue remains one, but it differs in its practical implementation. The anthropological-axiological level of virtue is discussed by St. Mark in Justif. 24 and Bapt. IX 78-79. In this case, we can see the author's striving to emphasize the role of God and his grace in the work of human salvation. 
Salvation is seen as an action that transcends human nature, and virtue remains a natural state of man, a state that is in turn not possible without the help of God's grace. The ascetic-practical level is related to looking at virtue in the context of prayer. Prayer is a mediator between God and man. Through it, man receives the grace that generates virtue in him, that is why it can be called "mother of virtues". 